\title{
Pragmatic Analysis On The Implementation Of Maxim Of Quantity On "Exclusive Prabowo Subianto With Dalton Tanonaka" News Interview And Its Implication On Teaching Speaking
}

\author{
Ghania Rizky El Haq, Suparno, Hefy Sulistyawati \\ English Education Department \\ Teacher Training and Education Faculty \\ Sebelas Maret University of Surakarta
}

Email: ghaniarizkye@gmail.com

\begin{abstract}
The article is based on a research which aims at 1) finding out how maxims of quantity are flouted in the news interview, 2) what causes it, and 3) the purposes of flouting maxims of quantity in "Exclusive Prabowo Subianto with Dalton Tanonaka". It is conducted using descriptive qualitative method seen from the point of view of pragmatics. The data are collected by choosing 30 of Prabowo Subianto's utterances which contain flouting of maxim of quantity. The analysis of the data used interactive model. From 30 utterances analyzed, the speaker flouts the maxim of quantity because the utterances contain more information than is required. The causes of maxim flouting are the speaker's dissatisfaction, knowledge/fact sharing, and protecting speaker's self-esteem, while the purposes are the intention of showing off, the desire of avoiding misunderstanding, the silence of speaking partner, and the desire of providing clear information.
\end{abstract}

Keywords: pragmatics, cooperative principles, maxim of quantity, flouting of maxim

\section{INTRODUCTION}

People are social creatures who need to socialize with others in their daily life. In socializing, they do communication that is exchanging idea or information to each other purposely. Keyton (in Lunenburg, 2010: 1) says, "Communication is the process of transmitting information and common understanding from one person to another".

There are two agents in communication, sender/speaker and receiver/hearer. Speaker is the one who delivers message to the speaking partner, while hearer is the one who receives the message from the speaker. When one communicates with other, he must expect feedback from the speaking partner; it could be just a nod, any other kind of gestures, or a response. The feedback shows that the hearer understands the idea/information delivered. There are two kinds of communication; one-way and two-way communication. In one-way communication, one does not need any feedback from the hearer, like communication we find in radio and television which does not need feedback from the hearers or the audiences. While in two-way communication, it needs feedback from the speaking partner. It can be done directly (face to face) or indirectly (letters, telephone, emails).

From the explanation above, we can conclude that communication can be done either directly or indirectly, and of course the ways support the communication to take place are also different. It could be face-to face, telephone call, e-mail, or written report. By seeing the ways communication 
occurs, we can conclude that it is either in the form of spoken or written interaction.

In life, activities that one does may not always run as smooth as he wants it to be, it is as well as in communication. When one communicates with others, he may find difficulties in catching the meaning of their utterances. The causes of the difficulties to understand the message is called noise. Lunenburg (2010: 2) says, "Noise is anything that distorts the message. Different perceptions of the message, language barriers, interruptions, emotions, and attitudes are examples of noise". Using sensitivity by looking at speaking partner's face expression and gestures can help us to avoid noise. Moreover, enhancing vocabularies and knowledge can help us avoiding noise as well.

Grice (in Sarala Krishnamurthy, Elina Ithindi, Alec Brewis and Juliet Eiseb, 2009: 207) says, "Conversations take place successfully because humans follow a behavioural command called cooperative principle. This can be seen as the commitment between speakers and listeners, to work together to create meaningful conversations". In reality, people sometimes or even often deliver more information or less information than it should be, being irrelevant, not being truthful, and ambiguous. Pragmatically, this kind of phenomenon is called flout of maxim.

Grice (in Thomas, 1995: 63-64; in Yule, 1996: 37; in Levinson, 1983: 101-102) proposes conversational rules named Cooperative Principles. There are four rules in Cooperative Principles; maxim of quantity, maxim of quality, maxim of relevance, and maxim of manner. By following the mentioned rules, Grice believes that conversation will run smoother. However, many people have not followed them yet for certain purposes. There are internal and external factors influencing them for not following/observing the maxims. The internal factors are the desire of impressing to other speakers their knowledge, speaking ability, achievements, and any of one's positive sides, and the wish of keeping pride in front of others. The external factor is force from others for not giving information about certain matters.

This research focused on the analysis of maxim of quantity in news interview entitled "Exclusive Prabowo Subianto with Dalton Tanonaka". The duration of the news interview is 43 minutes 46 seconds. Dalton Tanonaka is the interviewer/host of the news interview, while Prabowo Subianto is the interviewee/guest. The news interview is about Prabowo's past life (army life, incidents of May 1998, and personal life) and his plan for joining presidential election.

This research aims to find out how maxims of quantity are flouted in the news interview, what causes it, and the purposes of the flouting of the maxim of quantity in "Exclusive Prabowo Subianto with Dalton Tanonaka".

\section{RESEARCH METHODS}

The news interview programme, as has been mentioned above, entitled "Exclusive Prabowo Subianto with Dalton Tanonaka". It is a weekly programme broadcasted in Metro TV in 2009, every Sunday morning at 8 , with Dalton Tanonaka as the host. The episode with Prabowo Subianto as the guest was on 29 March 2009.

This research is done by using descriptive qualitative method. Nawawi (1994: 73) defines descriptive method as a problem-solving procedure, by describing the state of the object in the present study, based on the facts that appear or as they are.

There were 30 pages of the video transcript, but not the whole script was analyzed. The researcher only took the 
utterances of Prabowo Subianto to be analyzed because he was the interviewee in the news interview who answers questions and responds statements of Dalton as the interviewer.

Fraenkel and Wallen (2009: 90) say, "A sample in a research study is the group on which information is obtained". The writer used purposive sample to select the data. Sutopo (2006: 64) defines purposive sampling as a technique to select data based on specific access which is considered to have information related to the issues in depth and can be trusted to be a steady source of data. The sample of the research is 30 utterances of Prabowo Subianto which are considered containing flouting of maxim of quantity in the script of "Exclusive Prabowo Subianto with Dalton Tanonaka" news interview. The researcher applied the cooperative principles of Grice focusing on maxim of quantity to analyze Prabowo's utterances.

The steps of collecting the data are 1) watching some episodes of the Exclusive interview with Dalton Tanonaka, 2) choosing the best topic to be identified, 3 ) identifying the interviews which have been chosen, 4) deciding the interview to be identified, 5) watching the interview, 6) transcribing the whole dialogues in the interview, 7) identifying the dialogues in script of the interview, 8) selecting the dialogues which contain maxim of quantity, 9) giving code for the participant of the interview who becomes the object of the research, 10) giving code for each data, for example: 01/PS/00.01.11, 11) doing deep analysis of the listed dialogues contain Grice's maxims and the Cooperative Principle.

To analyze the data, writer uses steps as proposed by Miles and Huberman: data reduction, data display, and conclusion drawing/verification. In data reduction, data will be selected and eliminated based on theory of flouting of maxim of quantity. The next step is data display which contains two steps: describing the context of dialogues which contains maxim of quantity and analyzing the flout of maxim of quantity and its purpose. And the last step is drawing the conclusion whether Prabowo flouts maxim of quantity by giving more information or less information than it is required.

\section{RESEARCH $\quad$ FINDINGS AND DISCUSSIONS}

From the utterances which contain flout of maxim of quantity in the news interview "Exclusive Prabowo Subianto with Dalton Tanonaka", researcher chose only 30 utterances to be analyzed. The analysis includes the context during the flout of maxim occurs, how the maxim is flouted, and why the maxim flouts occur. In analyzing the utterances of Prabowo, researcher uses Grice's Cooperative Principle focusing on maxim of quantity.

There are three causes and four purposes of the maxim flout as being found in the news interview. The three causes are speaker's dissatisfaction, knowledge/fact sharing, and protecting speaker's selfesteem. While the four purposes of maxim flout are intention of showing off, desire of avoiding misunderstanding, silence of the speaking partner, and desire of providing clear information.

In datum 10/P/00.13.15, Prabowo flouts the maxim because he wants to share knowledge/fact, and he purposely does that to show off. The situation is that Prabowo was still delivering his answer, when he came to the word "pluralism", he got difficulty to pronounce it and asked Dalton how to pronounce it and has he pronounced it correctly or not. 
Dalton: Yes, you are right, plu plu plu pluralism. Ya.

Prabowo: I just came from so many hours of campaign.

Dalton: No, I know.

Prabowo flouts the maxim by telling more information which is out of topic that he just came from many hours of campaign. He might have told Dalton about this before the video shoot, and here he re-tells it to Dalton as well as to the audiences to let them and everybody knows about it.

In datum $27 / \mathrm{P} / 00.36 .15$, it shows that Prabowo is kind of being forced to flout the maxim of quantity because of the silence of Dalton as well as to share knowledge/fact. The situation is that Dalton asks Prabowo about his relation with Suharto's family, and Prabowo gives general overview of their relation. Dalton actually expects Prabowo to tell about the incident in a family meeting. Prabowo does not catch the actual meaning of Dalton by asking so, and finally Dalton asks explicitly what he really wants to ask.

Dalton: Mm how are you with the Suharto's today?

Prabowo: Mm..I think better better one time I think they..they considered me some sort of mm I mean I think I think one time I was accused of being a traitor to the family. came up to you in like stuck a finger in your face it had never step foot in my house again, is that true?

Prabowo: Yes, it was true actually, yes. But, you know, this is the that's why I work one of the reasons why I do believe in democracy, you know, and freedom of the press because $\mathrm{mm}$ in an authored authoritarian mm system regime, $\mathrm{mm}$ you know, palace intrigue and rumours can mm make mm mm perception seem real, you know, there there are always people who are whispering, you know, $m$ in the years of the the people around the the great leader, you know, I think that that this is $m$ this is the the weakness of an authoritarian closed....

In the dialogue above, actually Dalton does not blatantly deliver his meaning. It shows by his silence when Prabowo only answers "Yes, it was true actually, yes". He actually expects more information will be given by Prabowo.

From the research findings and the discussion above, the conclusion can be drawn as follows: 1) Prabowo Subianto flouted the maxim of quantity by delivering more information than is required, 2) The causes of maxim flout are the speaker's dissatisfaction, knowledge/fact sharing, and protecting speaker's self-esteem, 3) The

Table 1: Causes (Reasons) of Maxim Flouting, The Number of Utterance evaluated, and its

\begin{tabular}{|c|c|c|c|c|}
\hline \multicolumn{5}{|c|}{ percentage } \\
\hline No & Causes (Reasons) of Maxim Flouting & Data & Number of utterance evaluated & Percentage \\
\hline 1 & Speaker's dissatisfaction & 3 & $4,7,8$ & 10 \\
\hline 2 & Knowledge/fact sharing & 14 & $\begin{array}{l}1,2,5,6,9,10,17,18,21,24 \\
27,28,29,30\end{array}$ & 46.67 \\
\hline 3 & Protecting speaker's self esteem & 13 & $\begin{array}{l}3,11,12,13,14,15,16,19,20 \\
22,23,25,26\end{array}$ & 43.33 \\
\hline & Total & 30 & & 100 \\
\hline
\end{tabular}

Dalton: I mean I I read accounts where had a family meeting somebody purposes of maxim flout are the intention of showing off, the desire of avoiding 
misunderstanding, the silence of speaking partner, and the desire of providing clear and Eiseb, 2009: 207) proposes that following maxim of quantity in conversation

\begin{tabular}{cllll} 
Table 2: Purposes of Maxim Flouting, The Number of Utterance evaluated, and its Percentage \\
\hline No & \multicolumn{1}{c}{ Purposes of Maxim Flouting } & Data & Number of utterance evaluated & Percentage \\
\hline 1 & The intention of showing off & 4 & $10,13,16,20$ & 13,33 \\
2 & The desire of avoiding misunderstanding & 9 & $1,5,7,8,11,12,17,18,24$ & 30 \\
3 & The silence of speaking partner & 1 & 27 & 3,33 \\
4 & The desire of providing clear information & 16 & $2,3,4,6,9,14,15,19,21$, & 53,33 \\
& & & $22,23,25,26,28,29,30$ & \\
& Total & 30 & & 100 \\
\hline
\end{tabular}

information.

These tables below summarizes the causes and purposes of maxim flouting and each percentage of it

As mentioned before that the episode of the news interview which inviting Prabowo as the guest was in 2009. It was the year of a presidential election, and was the very first time for Prabowo standing for the election. Another reason of inviting Prabowo is that he is a man who has the most unique background of life as someone who is being accused of being involved in the biggest riot in Indonesia. So, beside aiming to provide information about the vision and mission of one of presidential candidates, the news interview aims to provide the background and past life of Prabowo.

Since the programme "Exclusive Prabowo Subianto with Dalton Tanonaka mais to provide information about his background and past life, the topic of the news interview was about the issue of his involvement in the riot in May 1998, the reasons of his leaving to Jordan, his relationship with Suharto's family, and his plan of becoming the next president of Indonesia.

The research findings are in line with the theory proposed by Grice and Thomas. Grice (in Krishnamurthy, Ithindi, Brewis will lead the conversation to become smooth. Thomas (1995: 122) says that people use indirectness to get advantages or to evade negative consequences. They may intend to hurt others, show how smart they are, avoid taboo topics, etc. But whatever their motivation is, it is to make a speaker achieve his goal or to evade unpleasantness. From the utterances delivered by Prabowo, none of them observe maxim of quantity, but each utterance has its own cause/reason and purpose of not observing it.

Besides proving the theory of Grice and Thomas, the research findings also prove what has been said by Levinson (1983: 102) that it is impossible that one always observes maxims in oral conversation every time, and it is proved that it is impossible for Prabowo to observe one of conversational implicatures because he is often forced to flout the maxim for the goodness of him himself as well as Dalton and all audiences.

Inviting Prabowo is kind of golden chance, that is why digging information as deep as possible is sure to happen. For some times, Dalton looks forcing Prabowo about certain information though Prabowo has clearly said that he cannot tell more about it. Prabowo has strong considerations of flouting maxim of quantity in each of his utterance. In short, observing cooperative 
principle is proved to help people creating a smoother conversation, but frequently people disobey it for certain purposes depending on the context of the conversation.

\section{CONCLUSIONS AND SUGGESTIONS}

From the research findings, it can be concluded that:

1. 30 of Prabowo Subianto's utterances contain flouting of maxim of quantity with certain reasons and purposes. The causes/reasons are speaker's dissatisfaction, knowledge/fact sharing, and protecting speaker's self-esteem. Meanwhile, the purposes are intention of showing off, desire of avoiding misunderstanding, silence of speaking partner, and desire of providing clear information. Knowledge/fact sharing and desire of providing clear information are the most frequent reason and purpose of Prabowo to flout the maxim, while self esteem and desire of avoiding misunderstanding are the second most ones. From the result of the analysis, it shows that maxim flouting done by Prabowo is for the goodness of people as well as him.

2. The causes/reasons and purposes of maxim flouting are influenced by internal and external factors. The internal factors of maxim flouting are Prabowo's dissatisfaction, his dsire to share knowledge/fact, the desire to protect his self-esteem, the intention of showing off, the desire to avoid misunderstanding, and the desire to provide clear information. While the external factor is Dalton's silence.

3. The maxim flouting are delivered as implicatures rather than explicatures.

4. A person's emotion at certain time may influence him to flout maxim. Passionate feelings may cause someone to talk much more and flout maxim. There are some of Prabowo's utterances that sound emotional when uttered, but since the emotion controlling is good, Prabowo can manage it well just in a few seconds.

5. Talking effectively will make one to be respected more. In the interview, there are some parts when Dalton cuts Prabowo's explanation which he thinks out of the core of the questions. In turntaking, a hearer will give the right amount of time for a speaker to speak as long as he cooperatively gives the hearer information. On the other side, when the hearer finds the speaker not cooperative, he will cut the speaker's utterance and re-ask, re-assert his meaning, etc.

Communication is human's daily need, and it has a strong relation with pragmatics. Because of its importance, pragmatics needs to be explored more. This article talks about one of parts in pragmatics, while there are still many parts of pragmatics need to be noted. The researcher hopes that this can be considered by other researchers to hold researches focusing on pragmatics in the future, whether it focuses on other maxims in Cooperative Principle (maxim of quality, relation, and manner) or in other branches of pragmatics.

The teaching of context as this research suggested is important not only for people in the related fields, but also important to be taught to students especially in teaching speaking, so that they will be able to speak not only based on rules written in books, but also able to speak in a wider topic.

\section{BIBLIOGRAPHY}

Fraenkel, Jack R., \& Wallen, Norman E. 2009. How to Design and Evaluate 
Research in Education: Seventh Edition. New York: McGraw-Hill.

Krishnamurthy, Sarala, Ithindi, Elina, Brewis, Alec, \& Eiseb, Juliet. 2009. Pragmatic Analysis of Students' Performance at the Polytechnic of Namibia. NJLC. Volume 3, 206-221.

Levinson, Stephen C. 1983. Pragmatics. Cambridge: Cambridge University Press.

Lunenburg, Fred C. 2010. Communication: The Process, Barriers, and Improving Effectiveness. Schooling. Volume 1, $1-11$.

Miles, Matthew B., \& Huberman A. Michael. 1994. An Expanded Sourcebook: Qualitative Data Analysis Second Edition. California: Sage Publications, Inc.

Nawawi, Hadari, \& Martini, Mimi. 1994. Penelitian Terapan. Yogyakarta: Gajah Mada University Press.

Pychil. 2009. Prabowo Subianto Interviewed by Dalton Tanonaka. Retrieved from http://ikastara.org/showthread.php?t= 1112 on 20 April 2014.

Sutopo, H.B. 2006. Metodologi Penelitian Kualitatif: Dasar Teori dan Terapannya dalam Penelitian. Surakarta: Sebelas Maret University Press.

Thomas, Jenny. 1995. Meaning in Interaction: An Introduction to Pragmatics. London: Longman Group Limited.

Yule, George. 1996. Pragmatics. Oxford: Oxford University Press. 